\title{
HIV and viral hepatitis co-infection in pregnancy: epidemiological, clinical and diagnostic review
}

\author{
Sávio Freire da Silva ${ }^{1}$, Roseane Mara Cardoso Lima Verde ${ }^{2}$, José \\ Felipe Pinheiro do Nascimento Vieira ${ }^{3}$, Leonardo Ferreira Soares ${ }^{4}$, \\ Matheus Hipólito do Nascimento ${ }^{5}$ and Evaldo Hipólito de Oliveira ${ }^{1 * *}$
}

${ }^{1}$ Universidade Federal do Piauí. Hospital Universitário. Campus Ministro Petrônio Portella. Ininga. Teresina-PI. Brazil (CEP 64049-550).*Email: evaldohipolito@gmail.com.

${ }^{2}$ Secretaria Estadual de Saúde do Piauí. Maternidade Dona Evangelina Rosa. Avenida Higino Cunha, 1552. Ilhotas. Teresina-PI. Brazil (CEP 64014-220).

${ }^{3}$ Secretaria Estadual de Saúde do Piauí. Laboratório Central de Saúde Pública. Rua 19 de Novembro, 1945. Primavera. Teresina-PI. Brazil (CEP 64002-570).

${ }^{4}$ Universidade Estadual da Paraíba. Centro de Ciências Biológicas, Sociais e Aplicadas. Rua Horácio Trajano de Oliveira, S/Nº . Cristo Redentor. João Pessoa-PB. Brazil (CEP 58070-450).

${ }^{5}$ Faculdade de Odontologia. Centro Universitário Unieuro. Setor de Clubes Esportivos Sul, Trecho 0, Conjunto 05. Asa Sul. Brasília-DF (CEP 70200-001).

\begin{abstract}
Even though the survival of the population infected with HIV has been increased due to the intensification of antiretroviral therapy, co-infection with hepatitis B or hepatitis C has attracted the attention of doctors and other health professionals regarding the increased incidence of chronic complications resulting from viral hepatitis in HIV-infected population, which differs from that with other opportunistic diseases. Women coinfected with these viruses have an increased risk of complications during pregnancy, and the vertical transmission of these infections cause significant morbidity and mortality among children. This study aimed to investigate the risks of co-infection with HIV, hepatitis B, and hepatitis C during pregnancy, through a literature review of the last ten years, using the databases LILACS, MEDLINE and SCIELO, which make up the Virtual Health Library. A total of 106 articles were found, by searching in these databases, 46 of which were pre-selected to be read in full, resulting in 15 approved articles. It was noted that most of the accepted studies were carried out in countries of sub-Saharan Africa and Europe, followed by Brazil and the United States. The presence of co-infections made the infection worse and led to disease progression, both in the mother and in the child, compared to infection with only one of these viruses. Therefore, early diagnosis and prevention and treatment are essential to reduce and prevent the vertical transmission of these viruses.
\end{abstract}

Keywords: Pregnancy; HIV; Hepatitis B; Hepatitis C; Co-infection.
Received

September 01, 2017

Accepted

December 19, 2017

Released

December 31, 2017

Open Access Full Text Article

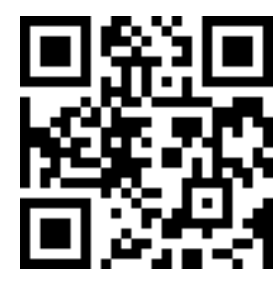

ORCID

(1) 0000-0002-6221-6910 Sávio Freire da Silva

(1) 0000-0002-0644-1291 Roseane Mara Cardoso Lima Verde

(D) 0000-0002-9049-1231 José Felipe Pinheiro do Nascimento Vieira

(1) 0000-0002-1225-3879

Leonardo Ferreira Soares 


\section{Introduction}

The emergence of AIDS as an epidemic occurred worldwide in the late 1970s, and the first cases were detected in the United States, Haiti, and Central Africa. At the beginning of this pandemic, the cases were restricted to a specific group, so the term "5 H Disease" was temporarily adopted since it was related to homosexuals, hemophiliacs, Haitians, heroin addicts, and hookers. The possible factors of transmission were already known in these groups. In 1983, the first cases arose in women (with an increase in vertical transmission, accounting for more than $80 \%$ of the cases in children under 13 years old), children and health professionals (Marques, 2012; Sousa et al., 2012).

HIV is a spherical particle with a diameter between 100 and $120 \mathrm{~nm}$, it belongs to the Family Retroviridae and genus Lentivirus, and its nucleus contains two copies of single-stranded RNA, encapsulated by a protein layer or nucleocapsid, capsid, and an outer envelope composed of a phospholipid bilayer (Veras, 2010).

Some studies carried out in the United States and Europe in recent years have shown that hepatopathies (chronic liver failure, cirrhosis, and hepatocarcinoma) have become a significant cause of hospitalization and death among patients, and it is currently the leading cause of death among HIV-infected patients, according to some health centers (Beringer et al., 2012).

Maternal infections can increase the perinatal morbimortality. For this reason, the screening of these diseases during prenatal care is important so that early diagnosis and treatment can be made when it is possible. Numerous maternal infections, which can be transmitted to the fetus, can occur during pregnancy, causing

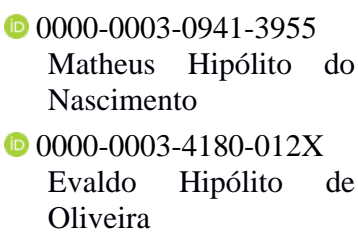

severe sequelae in the newborn, including AIDS and hepatitis B and hepatitis C. The failure to detect these infections early during prenatal care is a missed opportunity for intervention in the infected pregnant woman, limiting the possibilities of reducing the incidence of pediatric cases of vertical transmission infection (Newton, 1999; Miranda et al., 2009). Intrauterine infections and those acquired during childbirth are important causes of fetal and neonatal mortality and contribute significantly to infant morbidity (Miranda et al., 2012).

In Brazil, 92,210 HIV-infected pregnant women were notified from 2000 to June 2015, most of them in the Southeast region (40.5\%), followed by the South (30.8\%), Northeast (15.8\%), North (7.1\%) and Central-West (5.7\%) regions. Brazil accounted for 7,668 infected pregnant women identified in 2014, $35.1 \%$ in the Southeast, $28.1 \%$ in the South, $20.0 \%$ in the Northeast, $11.2 \%$ in the North, and $5.5 \%$ in the Central-West regions. The rate of detection of HIV-infected pregnant women has increased in Brazil in the last ten years; this rate was two cases per thousand live births in 2005 and increased to 2.6 in 2014 (Brasil, 2015a).

Vertical transmission (VT) of HIV-1 can occur in the intrauterine period, in the childbirth or during breastfeeding. The virus can be transmitted within the uterus by transplacental cellular transport, due to a progressive infection of the placental trophoblasts or ruptures in the placental barrier followed by microtransfusion from the mother to the fetus. Transmission during childbirth can occur by the contact of the fetus with the mother's infected secretions as it passes through the vaginal canal, by an infection upward from the vagina to the fetal membranes and the amniotic fluid, or by 
absorption into the digestive tract of the newborn. Breastfeeding is the main way of postpartum transmission. The vertical transmission route may be influenced by several factors, such as the type of childbirth, use of antiretroviral therapy, oral inflammation in the newborn, prematurity, and high maternal viral load (Rosa et al., 2015).

Antiretroviral therapy (ART) can be indicated for all HIV-infected pregnant women, regardless of clinical and immunological criteria, and it should not be discontinued after childbirth, irrespective of the level of LT-CD4+ at the beginning of the treatment. Permanent treatment for pregnant women living with HIV has a considerable potential to improve the mother's health and prevent transmission to her children and partners (ONUSIDA, 2013; Brasil, 2015b).

At the perinatal exposure, HBV mother-to-child transmission may occur in the childbirth by exposing the newborn to blood or amniotic fluid containing HBV, during passage through the vaginal canal, by the contact with secretions, during breastfeeding and, rarely, by transplacental transmission. Fetal infection with HBV depends on the mother's immune status and viral load (Silva et al., 2015).

According to data from the World Health Organization (WHO), between 130 and 150 million people worldwide have chronic hepatitis $\mathrm{C}$, and a significant number of those who are chronically infected will develop liver cirrhosis or liver cancer. Approximately 500,000 people die each year from liver diseases related to hepatitis C (WHO, 2015).

This study aimed to investigate, through an integrative review, the risks of co-infection with HIV, hepatitis B, and hepatitis $C$ in pregnancy, highlighting the epidemiological, clinical and diagnostic aspects of such infections during pregnancy.

\section{Methodology}

\section{Type of study}

The present study consists of an integrative review aimed at gathering and synthesizing research results on a given topic or issue, in a systematic and orderly manner, contributing to the improvement of the knowledge of the subject studied (Mendes et al., 2008). It differs from the traditional review because it tries to overcome possible biases in all the stages, following a method of search and selection; evaluation of the relevance and validity; collection, synthesis, and interpretation of the search data. Moreover, it promotes the updating of health professionals, since it provides them with further knowledge (Galvão et al., 2004).

\section{Guiding question}

"What are the possible risks to the mother, fetus or newborn when there is a co-infection associated with hepatitis B, hepatitis C, and HIV?”

\section{Inclusion criteria}

The review was performed based on studies that analyzed hepatitis B, hepatitis C and HIV co-infection in pregnancy, considering articles in Portuguese, Spanish or English with full text available in the databases between 2005 and 2015.

\section{Exclusion criteria}

Studies that did not analyze hepatitis B, hepatitis $\mathrm{C}$ and HIV coinfection in pregnancy were excluded; articles that did not have the full text available or those not published between 2005 and 2015 were not considered for the development of the present study.

\section{Descriptors used}

The following Health Sciences Descriptors (DECS) were used: "HIV", "hepatitis/hepatite B", "hepatitis/hepatite C" and "pregnancy/gravidez" written in English and Portuguese. The search for the articles was performed through the combination: "hiv AND hepatitis/hepatite b AND hepatitis/hepatite c AND pregnancy/ gravidez".

\section{Database}

A bibliographic survey was conducted on the Internet, selecting articles published by researchers in scientific journals indexed in the LILACS, MEDLINE and SCIELO databases, which compose the Virtual Health Library 
(BVS/BIREME). The BVS is a network of information management, knowledge exchange and scientific evidence in health, established by the cooperation between institutions and professionals in the production, intermediation, and use of scientific and technical information on health, in open and universal access on the Internet. It differs from other sources of information available on the Internet because it meets criteria for selection and quality control (BVS, 2016).

\section{Selection of articles}

The bibliographic search of the studies in the databases was performed at two stages:

- Initial search: Potential articles for the present study were identified, respecting the outlined inclusion criteria. The bibliographic search was carried out in the databases considering the years between 2005 and 2015 as a limit period. Articles in Portuguese, Spanish or English, with full text available in the databases, were selected. Then, articles with titles relating to our study were selected by eliminating the repeated ones. Afterwards, the abstracts of all articles were read.

- Detailed search: This stage consisted of reading, in full, all articles selected in the initial search for the application of the inclusion and exclusion criteria. articles

\section{Analysis and presentation of the}

The articles were read, and the data were collected from an instrument with the following variables: authors, year of publication, publication period, the country where the study was performed, and possible risks to the mother, fetus or newborn.

Tables contemplating the information previously mentioned were made to better analyze the data extracted from the articles included in the integrative review.

\section{Results and discussion}

Once the research is carried out, it is essential to publicize the results to the scientific community and experts, so that there are development and dissemination of knowledge and activities carrying out in a given area. The research begins to exist from the moment it is published, and the renewal of knowledge is driven by this socialization. In this sense, the scientific journals and, consequently, the scientific article itself play a fundamental role in achieving these aims (Curty and Boccato, 2005).

By searching for the descriptors "HIV, hepatitis B, hepatitis C and pregnancy" in Portuguese and in English, 37 and 106 published articles were found, respectively. However, it was observed that the 37 articles found using the descriptors in Portuguese were contained in the 106 articles obtained using these descriptors in English. Then, it was made the initial reading of the 106 articles, and 46 of them were selected for the detailed reading, resulting in 15 approved articles (Table 1).

Table 1. Distribution of the articles found and selected by databases.

\begin{tabular}{lcccc}
\hline Databases & Initial search & Detailed search & Excluded & Approved \\
\hline LILACS & 6 & 0 & 0 & 0 \\
MEDLINE & 100 & 46 & 31 & 15 \\
SCIELO & 0 & 0 & 0 & 0 \\
\hline Total & $\mathbf{1 0 6}$ & $\mathbf{4 6}$ & $\mathbf{3 1}$ & $\mathbf{1 5}$ \\
\hline
\end{tabular}

Regarding the databases, MEDLINE represented the largest number of published articles (Table 1). This finding is justified because it is a medical and biomedical international literature database, produced by the NLM, which has bibliographical references and abstracts of more than 4 thousand titles of journals published in the United States and in other 70 countries (BVS, 2016). 
There were few results from LILACS database (Table 1). It was selected because it is a Latin American database of bibliographical information in health sciences. This database has been produced by Bireme since 1982, with more than 500 titles of journals in 37 countries of Latin America and Caribbean (BVS, 2016). SCIELO was chosen because it is a Brazilian database; however, it showed no articles relating to the present study (Table 1).

The low number of approved articles, as shown in Table 1, can be justified by the fact there are ethical and legal obstacles to performed studies on pregnant women, making difficult a broad analysis of the possible risks caused by HIV/HBV/HCV co-infection in this group. Furthermore, many articles dealt with studies on patients with only one or two of these infections and were therefore excluded from this study.
Most of the studies (26.66\%) were carried out in countries of sub-Saharan Africa (Table 2), which accounted for 4 of the 15 studies selected. According to Ezechi et al. (2014), the prevalence of HBV infection is higher in low-income countries of sub-Saharan Africa and in Southeast Asia, where $8-10 \%$ of the patients are chronic carriers; these regions account for more than two-thirds of the global load of HIV. However, HCV is more prevalent in Western countries (Andreotti et al., 2014). European countries accounted for $26.66 \%$ of the studies, followed by Brazil and the United States with 20\% of the studies each (Table 2). According to Mohammadi et al. (2009), in the United States and Europe, the rate of $\mathrm{HIV} / \mathrm{HBV}$ co-infection varies from $6 \%$ to $14 \%$, whereas $\mathrm{HIV} / \mathrm{HCV}$ coinfection ranges from $25 \%$ to $50 \%$.

Table 2. Description of the analyzed articles.

\begin{tabular}{|c|c|c|c|}
\hline Title & Origin & \begin{tabular}{|l|l|} 
Journal \\
\end{tabular} & \begin{tabular}{|l|} 
Author \\
\end{tabular} \\
\hline $\begin{array}{l}\text { Pregnancy is associated with elevation of liver enzymes in HIV-positive women on } \\
\text { antiretroviral therapy }\end{array}$ & UK & Europe PMC & $\begin{array}{l}\text { Huntington et al. } \\
\text { (2015) }\end{array}$ \\
\hline $\begin{array}{l}\text { Sero-prevalence and factors associated with Hepatitis B and C co-infection in pregnant } \\
\text { Nigerian women living with HIV Infection }\end{array}$ & Nigeria & $\begin{array}{l}\text { The Pan African Medical } \\
\text { Journal }\end{array}$ & $\begin{array}{l}\text { Ezechi et al. } \\
(2014)\end{array}$ \\
\hline $\begin{array}{l}\text { The impact of HBV or HCV infection in a cohort of HIV-infected pregnant women } \\
\text { receiving a nevirapine-based antiretroviral regimen in Malawi }\end{array}$ & Malawi & BMC Infectious Diseases & $\begin{array}{l}\text { Andreotti et al. } \\
(2014)\end{array}$ \\
\hline $\begin{array}{l}\text { Prevalence of HBV, HDV, HCV, and HIV infection during pregnancy in Northern } \\
\text { Benin }\end{array}$ & Benin & Journal Medical Virology & $\begin{array}{l}\text { Paschale et al. } \\
(2014)\end{array}$ \\
\hline $\begin{array}{l}\text { Co-infections associated with human immunodeficiency virus type } 1 \text { in pregnant } \\
\text { women from southern Brazil: high rate of intraepithelial cervical lesions }\end{array}$ & Brazil & $\begin{array}{l}\text { Memónias do Instituto } \\
\text { Osvaldo Cruz }\end{array}$ & $\begin{array}{l}\text { Tomatore et al } \\
(2012) \\
\end{array}$ \\
\hline $\begin{array}{l}\text { Prevalence and temporal trends of hepatitis B, Hepatitis C, and HIV/AIDS co-infection } \\
\text { during pregnancy across the decade, 1998-2007 }\end{array}$ & USA & Journal of Women's Health & $\begin{array}{l}\text { Salihu et al. } \\
(2012)\end{array}$ \\
\hline Prevalence of sexually transmitted infections among HIV-infected women in Brazil & Brazil & $\begin{array}{l}\text { The Brazilian Journal of } \\
\text { Infectious Diseases }\end{array}$ & $\begin{array}{l}\text { Travassos et al. } \\
(2012)\end{array}$ \\
\hline Pregnancy outcomes associated with viral hepatitis & USA & Journal of Viral Hepatitis & $\begin{array}{l}\text { Reddick et al. } \\
\text { (2011) } \\
\end{array}$ \\
\hline $\begin{array}{l}\text { High rates of active hepatitis B and C co-infections in HIV-1 infected Cameroonian } \\
\text { adults initiating antiretroviral therapy }\end{array}$ & Cameroon & HIV Medicine & $\begin{array}{l}\text { Laurent et al. } \\
(2010)\end{array}$ \\
\hline $\begin{array}{l}\text { Prevalence and risk factors for HIV, syphilis, hepatitis B, hepatitis C, and HTLV-I/II } \\
\text { infection in low-income postpartum and pregnant women in Greater Metropolitan } \\
\text { Vitoria, Espirito Santo State, Brazil }\end{array}$ & Brazil & Caderno Saúde Pública & $\begin{array}{l}\text { Lima and Viana } \\
(2009)\end{array}$ \\
\hline $\begin{array}{l}\text { Survey of both hepatitis B virus (HBsAg) and hepatitis } \mathrm{C} \text { virus (HCV-Ab) coinfection } \\
\text { among HIV positive patients }\end{array}$ & Iran & Virology Journal & $\begin{array}{l}\text { Mohammadi et } \\
\text { al. (2009) }\end{array}$ \\
\hline Etravirine in special populations & Spain & $\begin{array}{l}\text { Enfermedades Infecciosas y } \\
\text { Microbiologia Clíica }\end{array}$ & Gil (2009) \\
\hline Prevention of mother-to-child transmission of viral infections & USA & $\begin{array}{l}\text { Current Problems in Pediatric } \\
\text { and Adolescent Health Care }\end{array}$ & $\begin{array}{l}\text { Read et al. } \\
(2008)\end{array}$ \\
\hline Viral infections of the fetus and newborm infant & Italy & $\begin{array}{l}\text { Medical and Surgical } \\
\text { Pediatrics }\end{array}$ & $\begin{array}{l}\text { Tremolada et al. } \\
(2008)\end{array}$ \\
\hline Hepatitis B or hepatitis C coinfection in HIV-infected pregnant $\mathrm{w}$ & $\begin{array}{l}\text { Spain, Italy, UK, Belgium, } \\
\text { Sweden, Gemany and } \\
\text { Ukraine }\end{array}$ & HIV Medicine & $\begin{array}{l}\text { Landes et al. } \\
(2008)\end{array}$ \\
\hline
\end{tabular}

Laurent et al. (2010) report that these co-infections are frequent in Europe and the United States, where the prevalence of HIV, HBV, and HCV in the general population is lower than in Africa. However, the predominant ways of transmission (intravenous drug use and sexual contact) of these infections are similar in Western countries, whereas in Africa such ways are very different (HIV by heterosexual relationship, HBV by close contact with the family during early childhood and by vertical transmission; regarding the $\mathrm{HCV}$, the ways of transmission are unclear). According to Ezechi et al. (2014) in the Western world, 
only $1 \%$ of the population is triply infected with HIV, HBV, and HCV.

In Brazil, the prevalence rates of HIV/HCV co-infection obtained from samples from health services are between $9.2 \%$ and $54.7 \%$, according to geographic distribution and risk factors for its acquisition. The highest prevalence rates are observed in studies that include injecting drug users in their sample, being the most important risk factor for HCV acquisition. The prevalence rates of HIV/HBV co-infection obtained in Brazilian studies using samples from health services are between 5.3\% and 24.3\% (Brasil, 2008). The higher prevalence rate of $\mathrm{HIV} / \mathrm{HCV}$ in comparison to the rate of HIV/HBV co-infection can be attributed to several factors, in particular, the lack of $\mathrm{HCV}$ vaccines and the existence $\mathrm{HBV}$ vaccines (Brasil, 2011b).

Women during pregnancy are exposed to viral agents that can be transmitted vertically to the fetus or newborn. Some of these viruses, as a result of vertical transmission, may induce clinically relevant damage to the fetus or newborn (Table 3). Pregnant women are at increased risk of sexually transmitted infections due to physiological changes that occur during pregnancy, such as congestion of the cervix, edema of the vaginal mucosa, and changes in the vaginal flora. In addition, they might be less likely to have partners who use condoms and may find it more difficult to abandon unsafe relationships (Tremolada et al., 2008; Travassos et al., 2012).

In pregnant women infected with HIV and coinfected with other sexually transmitted diseases (STDs), there may be an increase both in the risk of vertical transmission of HIV and of other pathogens (Table 3). This risk is especially pronounced if HIV infection is acquired during pregnancy. The HCV vertical transmission is increased from three to five times in the presence of HIV co-infection (Read et al., 2008; Travassos et al., 2012).

According to the Clinical Protocol and Therapeutic Guidelines for Prevention of Vertical Transmission of HIV, Syphilis and Viral Hepatitis (Brasil, 2015b), HBV infection in neonates has a higher chronification rate than in adults; in $90 \%$ of the infected neonates it evolves to the chronic form, and in the future it can cause cirrhosis and/or hepatocellular carcinoma (Table 3), differently from individuals who acquire this disease throughout life, since these have approximately a 30\% chance of developing chronic hepatitis B. Reddick et al. (2011) report that HBV has been associated with preterm birth and antepartum hemorrhage and that HCV has been associated with obstetric cholestasis and low birth weight infants (Table 3).

Table 3. List of possible risks of $\mathrm{HIV} / \mathrm{HBV} / \mathrm{HCV}$ co-infection during pregnancy, mentioned in the analyzed articles.

\begin{tabular}{ll}
\hline & Risks \\
\hline Mother & Antepartum hemorrhage; \\
& Elevation in hepatic enzymes; \\
& Obstetric cholestasis; \\
& Increase in the risk of hepatotoxicity associated with antiretroviral therapy. \\
& Premature birth; \\
& Intrauterine growth retardation; \\
& Higher possibility of vertical virus transmission; \\
& Possible selection of resistant virus. \\
& Increase in immunosuppression; \\
& Higher probability of acute or fulminant hepatitis, chronic liver failure, cirrhosis \\
and hepatocellular carcinoma.
\end{tabular}

According to Gil (2009) and Huntington et al. (2015), hepatotoxicity associated with antiretroviral therapy in
HIV-infected patients is more frequent in HCV/HBV-coinfected patients, since all classes or families of antiretroviral drugs 
can cause hepatotoxicity. In patients with chronic hepatitis without hepatocellular insufficiency, antiretroviral drugs can be used at usual doses. However, in patients with hepatocellular insufficiency, these drugs may change the metabolism and their bioavailability, which can increase toxicity. Huntington et al. (2015) highlight that the pregnancy itself may cause hepatotoxicity during antiretroviral therapy, with a $70 \%$ risk of increasing the number of hepatic enzymes (from mild to moderate) and a $260 \%$ risk of severely increasing this number (Table 3).

Current guidelines in the United States and Europe recommend the use of combined antiretroviral drugs for HIV/HBV coinfected individuals. Such treatment should consist of a combination of at least two anti-HBV active drugs (including lamivudine, tenofovir, and emtricitabine) to reduce the risk of developing HBV resistance mutations (Landes et al., 2008). However, it was observed by Landes et al. (2008) that, in Europe, most HIV/HBV-coinfected pregnant women were not using two of the anti-HBV active drugs in their antiretroviral treatment. Thus, the chances of selecting resistant $\mathrm{HBV}$, which can be transmitted to their children, are increased (Table 3).

Regarding the ideal therapy in HIV/HCV-coinfected pregnant women, it seems there is no consensus on this approach since the use of interferon alfa-2a during pregnancy is associated with abortion and the ribavirin has the potential for teratogenicity in animal models. Until now, according to the Clinical Protocol and Therapeutic Guidelines for Viral Hepatitis C and Coinfections (Brasil, 2011), there are no studies on the use of new drugs in HCVinfected pregnant women.

It was observed that $\mathrm{HIV} / \mathrm{HBV} /$ HCV co-infection made the infection worse and led to diseases progression. According to Mohammadi et al. (2009), infection with the three viruses causes a higher risk of acute or fulminant hepatitis, chronic liver failure, cirrhosis, hepatocellular carcinoma, and mortality (Table 3) than infection with only one of these viruses. HCV-seropositive women (and those with HBsAg) were significantly more immunosuppressed (Table 3) than HIV-mono-infected women, based on counts of CD4 cells, of which number were lower in women with antiHCV antibodies (Landes et al., 2008; Ezechi et al., 2014).

Tremolada et al. (2008) state that, by early diagnosis and appropriate prophylactic and therapeutic measures, it is possible to significantly reduce the risk of vertical transmission of these viruses and also reduce the severity of the damage caused by these infections. However, in developing countries, the availability and effectiveness of diagnostic, prophylactic and therapeutic intervention are much lower than in economically advanced countries. It occurs since vertically transmitted infections in developing countries still cause high morbidity and mortality (Bonney, 2016).

In view of this, the Brazilian Ministry of Health created the Stork Network in 2011, which is a strategy aimed at implementing a network of care to ensure women the right to reproductive planning and humanized attention to pregnancy, childbirth and puerperium, and ensure that children have the right to a safe birth and healthy growth and development (Brasil, 2015b).

\section{Conclusion}

Taking into consideration the risks described in several articles, it was evidenced that the early diagnosis of HIV, $\mathrm{HBV}$, and $\mathrm{HCV}$ in pregnant women is essential for the effective treatment in the prenatal and postnatal periods so that decisions can be made with the purpose of reducing and even preventing the vertical transmission of these viruses. Thus, it can also be evidenced that the development of strategies and public policies to control and prevent the transmission of these viruses in pregnant women are urgent measures to control these HBV, HCV and HIV infections in Brazil and worldwide. Moreover, there is a need for more epidemiological studies to better found the public policies focused on pregnant women.

\section{Conflict of interest statement}

Authors declare that they have no conflict of interests. 


\section{References}

Andreotti, M.; Pirillo, M. F.; Liotta, G.; Jere, H.; Maulidi, M.; Sagno, J. B.; Luhanga, R.; Amici, R.; Mancini, M. G.; Gennaro, E.; Marazzi, M. C.; Vella, S.; Giuliano, M.; Palombi, L.; Mancinelli, S. The impact of $\mathrm{HBV}$ or $\mathrm{HCV}$ infection in a cohort of HIV-infected pregnant women receiving a nevirapine-based antiretroviral regimen in Malawi. BMC Infectious Diseases, 14:180, 2014. https://doi.org/10.1186/1471-2334-14-180

Berenguer, J.; Pedrol, P. D.; Polo, R. (Coord.). Documento de consenso de Gesida/Plan Nacional sobre el Sida respecto al tratamiento antirretroviral en adultos infectados por el virus de la inmunodeficiencia humana (actualización enero de 2012). Enfermedades Infecciosas y Microbiología Clínica, v. 30, No. 6, p. e1-e89, 2012. https://doi.org/10.1016/j.eimc.2012. 03.006

Bonney, K. M. Promoting civic engagement with neglected tropical disease education. Brazilian Journal of Biological Sciences, v. 3, No. 5, p. 23-26, 2016. https://doi.org/ 10.21472/bjbs.030502

Brasil. Ministério da Saúde. Secretaria de Vigilância em Saúde. Departamento de DST, Aids e Hepatites. Boletim epidemiológico HIV-AIDS. Brasília: MS, 2015a.

Brasil. Ministério da Saúde. Secretaria de Vigilância em Saúde. Departamento de DST, Aids e Hepatites Virais. Protocolo clínico e diretrizes terapêuticas para prevenção da transmissão vertical de HIV, sífilis e hepatites virais. 1 ed. Brasília: MS, 2015b.

Brasil. Ministério da Saúde. Secretaria de Vigilância em Saúde. Departamento de DST, Aids e Hepatites Virais. Protocolo clínico e diretrizes terapêuticas para o tratamento da hepatite viral crônica $B$ e coinfecções. Brasília: MS, 2011a. (Série A. Normas e Manuais Técnicos).

Brasil. Ministério da Saúde. Secretaria de Vigilância em Saúde. Departamento de DST, Aids e Hepatites Virais. Protocolo clínico e diretrizes terapêuticas para hepatite viral $\mathbf{C}$ e coinfecções. Brasília: MS, 2011b. (Série A. Normas e Manuais Técnicos).

Brasil. Ministério da Saúde. Secretaria de Vigilância em Saúde. Departamento de Vigilância Epidemiológica. Hepatites virais: o Brasil está atento. 3. ed. Brasília; MS, 2008.

BVS - Biblioteca Virtual de Saúde. Available from: <http://bvsalud.org/>. Accessed on: Jan. 4, 2016.

Curty, M. G.; Boccato, V. R. C. O artigo científico como forma de comunicação do conhecimento na área de Ciências da Informação. Perspectivas em Ciência da Informação, v. 10, No. 1, p. 94-107, 2005. Available from: <http://portaldeperiodicos.eci. ufmg.br/index.php/pci/article/view/305/108>. Accessed on: Jan. 4, 2016.

De Paschale, M.; Ceriani, C.; Cerulli, T.; Cagnin, D.; Cavallari, S.; Ndayaké, J.; Zaongo, D.; Priuli, G.; Viganò, P.; Clerici, P. Prevalence of HBV, HDV, HCV, and HIV infection during pregnancy in Northern Benin. Journal of Medical Virology, v. 86, p. 1281-1287, 2014. https://doi.org/10.1002/jmv.23951

Ezechi, O. C.; Kalejaiye, O. O.; Gab-Okafor, C. V.; Oladele, D. A.; Oke, B. O.; Musa, Z. A.; Ekama, S. O.; Ohwodo, H.; Agahowa, E.; Gbajabiamilla, T.; Ezeobi, P. M.; Okwuraiwe, A.; Audu, R. R. A.; Okoye, R. N.; David, A. N.; Odunukwe, N. N.; Onwujekwe, D. I.; Ujah, I. A. Sero-prevalence and factors associated with Hepatitis B and C co-infection in pregnant Nigerian women living with HIV infection. The Pan African Medical Journal, 17:197, 2014. https://doi.org/10.11604/pamj.2014.17.197.2310

Galvão, C. M.; Sawada, N. O.; Trevizan, M. A. Revisão sistemática: recurso que proporciona a incorporação das evidências na prática da enfermagem. Revista Latino-Americana de Enfermagem, v. 12, No. 3, p. 549-556, 2004. https://doi.org/10.1590/S0104-11692004000 300014

Gil, I. S. Etravirina en poblaciones especiales. Enfermedades Infecciosas y Microbiologia Clinica, v. 27, p. 40-45, 2009. https://doi.org/ 10.1016/S0213-005X(09)73218-5

Huntington, S.; Thorne, C.; Newell, M. L.; Anderson, J.; Taylor, G. P.; Pillay, D.; Hill, T.; Tookey, P. A.; Sabin, C., on behalf of the UK Collaborative HIV Cohort (UK CHIC) Study and the UK and Ireland National Study of HIV in Pregnancy and Childhood (NSHPC). Pregnancy is associated with elevation of liver enzymes in HIV-positive women on antiretroviral therapy. AIDS, v. 29, No. 7, p. 801-809, $2015 . \quad$ https://doi.org/ 10.1097/QAD.0000000000000620

Landes, M.; Newell, M. L.; Barlow, P.; Fiore, S.; Malyuta, R.; Martinelli, P.; Posokhova, S.; Savasi, V.; Semenenko, I.; Stelmah, A.; Tibaldi, C.; Thorne, C. Hepatitis B or hepatitis C coinfection in HIV-infected pregnant women in Europe. HIV Medicine, v. 9, No. 7, p. 526-534, 2008. https://doi.org/10.1111/j.1468-1293.2008. 00599.x

Laurent, C.; Bourgeois, A.; Mpoudi-Ngolé, E.; Kouanfack, C.; Ciaffi, L.; Nkoué, N.; Mougnutou, R.; Calmy, A.; Koulla-Shiro, S.; Ducos, J.; Delaporte, E. High rates of active hepatitis $\mathrm{B}$ and $\mathrm{C}$ co-infections in HIV-1 
infected Cameroonian adults initiating antiretroviral therapy. HIV Medicine, v. 11, No. 1, p. 85-89, 2010. https://doi.org/10.1111/ j.1468-1293.2009.00742.x

Lima, L. H. M.; Viana, M. C. Prevalence and risk factors for HIV, syphilis, hepatitis B, hepatitis $\mathrm{C}$, and HTLV-I/II infection in lowincome postpartum and pregnant women in Greater Metropolitan Vitória, Espírito Santo State, Brazil. Caderno de Saúde Pública, v. 25, No. 3, p. 668-676, 2009. https://doi.org/ 10.1590/S0102-311X2009000300021

Marques, M. C. C. Saúde e poder: a emergência política da Aids/HIV no Brasil. História, Ciências, Saúde-Manguinhos, v. 9, p. 41-65, 2012. https://doi.org/10.1590/S0104-59702 002000400003

Mendes, K. D. S.; Silveira, R. C. C. P.; Galvão, C. M. Revisão integrativa: método de pesquisa para a incorporação de evidências na saúde e na enfermagem. Texto \& Contexto Enfermagem, v. 17, No. 4, p. 758-64, 2008. https://doi.org/10.1590/S010407072008000400018

Miranda, A. E.; Rosetti-Filho E.; Trindade, C. R.; Gouvêa, G. M.; Costa, D. M.; Oliveira, T. G. Prevalência de sífilis e HIV utilizando testes rápidos em parturientes atendidas nas maternidades públicas de Vitória, Estado do Espírito Santo. Revista da Sociedade Brasileira de Medicina Tropical, v. 42, No. 4, p. 386-391, 2009. https://doi.org/10.1590/ S0037-86822009000400006

Miranda, M. M. S; Souza, L. M. G.; Aguiar, R. A. L. P.; Corrêa Jr., M. D.; Maia, M. M. M.; Borges, R. S.; Melo, V. H. Rastreamento das infecções perinatais na gravidez: realizar ou não? FEMINA, v. 40, No. 1, p. 13-22, 2012. Available from: <http://files.bvs.br/upload/ S/0100-7254/2012/v40n1/a3075.pdf $>$. Accessed on: Jan. 4, 2016

Mohammadi, M.; Talei, G.; Sheikhian, A.; Ebrahimzade, F.; Pournia, Y.; Ghasemi, E.; Boroun, H. Survey of both hepatitis B virus (HBsAg) and hepatitis $\mathrm{C}$ virus (HCV-Ab) coinfection among HIV positive patients. Virology Journal, 6:202, 2009. https://doi.org/ 10.1186/1743-422X-6-202

Newton, E. R. Diagnosis of perinatal TORCH infections. Clinical Obstetrics and Gynecology, v. 42, No. 1, p. 59-70, 1999.

ONUSIDA - Programa Conjunto de las Naciones Unidas sobre el VIH/SIDA. Tratamento 2015. Geneve: ONUSIDA, 2015. Available from: <http://www.unaids.org/ sites/default/files/en/media/unaids/contentassets /documents/unaidspublication/2013/JC2484_tre atment-2015_pt.pdf>. Acessed on: Jan. 31, 2016.

Read, J. S.; Cannon, M. J.; Stanberry, L. R.; Schuval, S. Prevention of mother-to-child transmission of viral infections. Current Problems in Pediatric Adolescent Health Care, v. 38, No. 9, p. 274-297, 2008. https://doi.org/10.1016/j.cppeds.2008.08.001

Reddick, K. L. B.; Jhaveri, R.; Gandhi, M.; James, A. H.; Swamy, G. K. Pregnancy outcomes associated with viral hepatitis. Journal of Viral Hepatitis, v. 18, No. 7, p. 394-398, 2011. https://doi.org/10.1111/ j.1365-2893.2011.01436.x

Rosa, M. C., Lobato, R. C.; Gonçalves, C. V.; Silva, N. M.; Barral, M. F.; Martinez, A. M.; Hora, V. P. Evaluation of factors associated with vertical HIV-1 transmission. Jornal de Pediatria, v. 91, No. 6, p. 523-528, 2015. https://doi.org/10.1016/j.jped.2014.12.005

Salihu, H. M.; Connell, L.; Salemi, J. L.; August, E. M.; Weldeselasse, H. E.; Alio, A. P. Prevalence and temporal trends of hepatitis $\mathrm{B}$, hepatitis C, and HIV/AIDS co-infection during pregnancy across the decade, 1998-2007. Journal of Women's Health, v. 21, No. 1, p. 66-72, 2012. https://doi.org/10.1089/ jwh.2011.2979

Silva, C. F.; Araújo, C. L. F.; Araújo, M. M. Oferta do teste sorológico para Hepatite B durante o pré-natal: a vivência das puérperas. Revista Enfermagem Uerj, v. 23, No. 1, p. 58-63, 2015. https://doi.org/10.12957/reuerj. 2015.4935

Sousa, A. M.; Lyra, A.; Araújo, C. C. F.; Pontes, J. L.; Freire, R. C.; Pontes, T. L. A política de AIDS no Brasil: uma revisão de literatura. Journal of Management \& Primary Health Care, v. 3, No. 1, p. 62-66, 2012. Available from: $\quad<$ http://www.jmphc.com.br/saudepublica/index.php/jmphc/article/view/119/120>. Acessed on: Jan. 31, 2016.

Tornatore, M.; Gonçalves, C. V.; Bianchi, M. S.; Germano, F. N.; Garcés, A. X.; Soares, M. A.; Machado, E. S.; Martinez, A. M. B. Coinfections associated with human immunodeficiency virus type 1 in pregnant women from Southern Brazil: high rate of intraepithelial cervical lesions. Memórias do Instituto Oswaldo Cruz, v. 107, No. 2, p. 205210, 2012. https://doi.org/10.1590/S007402762012000200009

Travassos, A. G. A.; Brites, C.; Netto, E. M.; Fernandes, S. A.; Rutherford, G. W.; Queiroz, C. $\mathrm{M}$. Prevalence of sexually transmitted infections among HIV-infected women in Brazil. The Brazilian Journal of Infectious Diseases, 
$\begin{array}{lll}\text { v. 16, } & \text { No. 6, } & \text { p. 581-585, }\end{array}$ https://doi.org/10.1016/j.bjid.2012.08.016

Tremolada, S.; Delbue, S.; Ferrante, P. Viral infections of the fetus and newborn infant. Medical and Surgical Pediatrics, v. 30, No. 4, p. 177-191, 2008. Available from: <https://www.ncbi.nlm.nih.gov/pmc/articles/PM C2698175/pdf/nihms99102.pdf $>$. Accessed on: Jan. 31, 2016.

UNAIDS. AIDS by the numbers 2015. World AIDS Day 2015. Available from: $<$ http://www.unaids.org/en/resources/documents /2015/AIDS_by_the_numbers_2015>. Accessed on: Jan. 18, 2016.

Veras, N. M. C. História evolutiva do HIV-1 no Brasil. Brasília: Universidade de Brasília, 2010. (Thesis). Available from: <http://repositorio.unb.br/handle/10482/7430>. Accessed on: Jan. 11, 2016.

WHO - World Health Organization. 2015. Available from: <http://www.who.int/ mediacentre/factsheets/fs204/en/> . Accessed on: Jan. 28, 2016. 